Гудима О. П., канд. техн. наук, ст. наук. співроб.

(0000-0002-3494-8583)

Центр воєнно-стратегічних досліджень Національного університету оборони України імені Івана Черняховського, Київ

\title{
Аналіз науково-методичного апарату формування організаційно- функціональних структур систем стратегічного рівня
}

Резюме. Проведено аналіз використання традиційних підходів до реалізації структурного синтезу складної системи та використання ситуаційного підходу. Збільшення кількості та щільності потоку кризових ситуацій відпрацьовується в системах збільшенням елементів структури, що потребує удосконалення методів структурно-параметричного синтезу складних організаційно-функціональних структур систем.

Ключові слова: науково-методичний апарат; організаційно-функціональна структура системи; ситуаційне управління; кризова ситуація; надмірність; структурно-параметричний синтез.

Постановка проблеми. Сучасні міжнародні конфлікти на сьогодні не можна оцінювати 3 погляду традиційних підходів до ведення бойових дій, їх можна охарактеризувати терміном “гібридна війна", яка $є$ комбінацією традиційних і нетрадиційних методів ведення війни.

Водночас, кожна країна світу постійно стикається в різних сферах своєї діяльності із загрозами, які можуть вплинути на економічні показники та стабільність функціонування самої держави. Кожна загроза (потенційна та реальна) може перерости в кризову ситуацію (КС) різного рівня. КС вважається крайнє загострення протиріч, гостра дестабілізація становища в будь-якій сфері діяльності, регіоні, країні [1].

Зазначене підтверджує і поява пандеміі COVID-19, яка змусила всі держави світу ситуативно реагувати на загрози та приймати непопулярні рішення щодо зменшення іiі наслідків [2].

Можливими варіантами дій щодо реагування на КС є: реагування на виникаючі $\mathrm{KC}$; прогнозування появи КС i завчасне запобігання їх виникненню.

Раннє запобігання (реагування) створює сприятливе підгрунтя для визначення цілей, вироблення можливих планів дій i $\ddot{i x}$ порівняння, аналізу можливого застосування обраного варіанта i реакції конфліктуючих сторін, а також розроблення вірогідних сценаріїв розвитку ситуації. Зважаючи на важливість раннього запобігання, в усіх заходах, спрямованих на врегулювання криз i запобігання конфліктам, значна увага приділяється отриманню, оцінюванню та аналізу інформації на ранніх етапах [3].

Як за першим так і за другим варіантом дій спостерігається певна закономірність. За умови достатньої частоти появи КС (за певними напрямами) створюються додаткові організаційно-функціональні структури (ОФС) в складі відповідних систем (постійні чи тимчасові) для відпрацювання відповідного потоку КС.

Так, наприклад, у разі збільшення щільності появи загроз, які можуть призвести надалі до КС в інформаційній сфері відповідно до [4] створено Центр протидії дезінформації. Центр протидії дезінформації створюється для досягнення цілей i завдань Стратегії національної безпеки України, протидії поточним i прогнозованим загрозам національній безпеці та національним інтересам України в інформаційній сфері, а також для забезпечення інформаційної безпеки України, ефективної протидії пропаганді, деструктивним дезінформаційним впливам та кампаніям, недопущення маніпулювання громадською думкою [4].

Як показує практика, під час побудови ОФС систем стратегічного рівня широкого використання набули експертні методи, які мають низку суттєвих обмежень і недоліків, основними 3 яких $є$ суб'єктивність і великий час для набуття відповідних спроможностей щодо реагуванню на КС.

Під ОФС систем стратегічного рівня розуміється система взаємозв'язків і підпорядкованість організаційних одиниць (підрозділів), які характеризуються чітким розподілом функцій для забезпечення поставлених завдань та проєктування організаційних форм управління на рівні вищого державного (військового) керівництва.

Прикладами ОФС систем стратегічного рівня $\epsilon$ : система протиповітряної оборони України; Командування повітряно-космічної оборони Північної Америки 
(NORAD) - об'єднана система аерокосмічної оборони США та Канади, основними завданнями якої $є$ забезпечення контролю за повітряним i навколоземним простором Північної Америки, раннього попередження про повітряно-космічний напад, протиповітряної і протиракетної оборони двох країн.

3 огляду на зазначене, доцільно провести аналіз існуючого науково-методичного апарату синтезу ОФС систем, виявити його недоліки та обмеження застосування, а також провести аналіз можливостей використання ситуаційного підходу для формування ОФС систем стратегічного рівня.

Аналіз основних публікацій. Структурний синтез складної системи, зокрема: етапи формування вимог до системи; вибір складових системи, рівня їх деталізації, формування варіантів побудови та опис взаємодії компонент; вибір оптимального варіанта побудови системи розглядались у працях [5-10]. Розв'язанню задачі параметричного синтезу складних систем присвячено роботи $[5,7-9]$.

У роботах [11-13] проведено аналіз використання ситуаційного підходу під час управління великими системами. Використання ситуаційного підходу під час синтезу системи забезпечення інформаційної безпеки було розглянуто в роботах [14-15].

Загалом, існуючі дослідження проводились, як правило, в межах існуючих підходів для вирішення певних часткових проблемних питань, але не було опрацьовано питання щодо формування ОФС систем стратегічного рівня (удосконалення ОФС систем стратегічного рівня) 3 урахуванням збільшення щільності появи КС.

Мета статті. Аналіз науковометодичного апарату формування ОФС систем стратегічного рівня (зокрема, можливості використання ситуаційного підходу), що дасть змогу визначити основні шляхи його подальшого розвитку 3 урахуванням збільшення щільності появи КС.

Виклад основного матеріалу. Будь-яка складна система визначається трьома категоріями: елементами, відношеннями, властивостями. Однозначний i повний опис цих категорій визначають систему, iіi структуру, параметри та ефективність. Метою синтезу системи є конкретизація і визначення оптимальних (раціональних) рішень для вказаних категорій. Зі свого боку синтез складної системи передбачає розв'язання задач структурного та параметричного синтезу.
Формування властивостей системи, вимог до неї та виконуваних функцій здійснюється на підставі аналізу особливостей застосовності розроблюваної системи та виконуваних 3 iі використанням завдань. Традиційні підходи до реалізації структурного синтезу складної системи можна умовно поділити на два класи. Перший полягає в евристичному синтезі структури, який базується на визначенні складових системи та відношень між ними на підставі аналізу виконуваних функцій і вимог до неї. Результатом такого підходу є суто суб'єктивні рішення про склад i структуру системи у вигляді одного безальтернативного варіанта. Такий підхід застосовується, як правило, у разі складного математичного опису (формалізації) задачі синтезу, а етап формування структури найчастіше називають розробленням $[16,17]$. Другий клас реалізації процесу побудови (синтезу) структури складної системи базується на використанні методів оптимізації і полягає у виборі з надмірної кількості варіантів побудови системи оптимальної структури за обраним критерієм, або системою критеріїв. Альтернативні варіанти побудови системи можна формувати як евристичними методами, так і з використанням методів математичного синтезу. Зі свого боку процедуру вибору оптимальної структури системи із сукупності альтернатив можна реалізувати 3 використанням оптимізаційних методів як за однокритеріальною, так i за багатокритеріальною моделлю $[9,18]$. Однокритеріальні оптимізаційні моделі мають відносну простоту реалізації етапів структурного синтезу, однак порівняно 3 багатокритеріальними моделями не забезпечують всебічного врахування в остаточних результатах синтезу усієї сукупності суперечливих вимог.

Для багатокритеріальних задач властиве застосування низки (вектора) суперечливих критеріїв. Саме наявність суперечності між частинними критеріями оптимальності системи не дає змоги розв'язувати задачу синтезу підходами, характерними для однокритеріальних задач. Суперечливість частинних критеріїв оптимальності виявляється в тому, що не можливо досягти оптимуму за всіма критеріями одночасно. Поліпшення одного критерію призводить до погіршення інших. У цьому разі застосовуються спеціальні методи розв'язання багатокритеріальних задач $[9,19]$. Можна виділити чотири класи основних методів розв'язання задач векторної оптимізації [19]: 
оптимізація послідовності частинних критеріїв у разі введення пріоритетів і призначенні поступок;

виділення парето-оптимальних рішень;

оптимізація на основі компромісних відношень;

наближення до певного ідеального значення.

Перевагою методів першого класу $\epsilon$ упорядкування критеріїв за значущістю i побудова процедур послідовної оптимізації за кожним частинним критерієм. Його недоліком можна вважати складності в обгрунтованості ранжування частинних критеріїв.

Суть методів другого класу полягає у визначенні сукупності рішень з області Парето 3 подальшим наданням права вибору єдиного 3 них особі, яка приймає рішення. Зазначені методи мають досить значну обчислювальну складність, а необхідність прийняття остаточного рішення із сукупності альтернатив, які належать області Парето, накладає додаткові обмеження на його використання. Особливо це виявляється саме у виборі оптимальних структур складних систем.

Методи третього класу (оптимізація на основі компромісних відношень) полягають у визначенні певного оптимального розв'язку 3 відомою поступкою між частинними критеріями оптимальності. У цьому разі формується узагальнений критерій оптимальності із сукупності частинних за певним правилом i визначається його екстремум відносно шуканого параметра оптимізації. Тобто фактично багатокритеріальна задача зводиться до однокритеріальної форми. Існує велика кількість способів формування узагальненого критерію [9, 19]. Перевагою цього класу методів є належність розв'язку області Парето. Саме ці методи широко застосовують для аналізу складних систем. До складностей методів третьої групи слід віднести обмеження, пов'язані із визначенням вагових коефіцієнтів частинних критеріїв.

Методи четвертого класу полягають у введенні певної ідеальної точки, яка належить області Парето, і наближенні оптимальних значень шуканих параметрів до неї за всіма частинними критеріями. Різноманітність критеріїв наближення породжує відповідно різноманітність існуючих методів цього класу за квадратичною, лінійною нормою та ін. $[9,19]$. Основним недоліком таких методів $є$ невизначеність або складності у формуванні ідеальної точки.

3 аналізу випливає, що найбільшого поширення набули методи багатокритеріальної оптимізації, які належать до третього i четвертого класів, однак щоразу вибір для використання певного методу залежить від специфіки та особливостей конкретної задачі. Практичній реалізації процесу структурного синтезу складних систем присвячено значну кількість робіт. Найбільш показові результати цього процесу подано в працях [17-20].

Параметричний синтез складної системи полягає у визначенні параметрів елементів заданої структури [19]. Розв'язання задачі параметричного синтезу потребує встановлення показників або критеріїв ефективності, формування оптимізаційної моделі параметричного синтезу системи та визначення оптимальних параметрів.

Система критеріїв може встановлюватись евристичним методом і мати ієрархію функцій - факторів - показників критеріїв. Перший підхід має більш обумовлений характер показників (критеріїв) i застосовується, як правило, на етапі розроблення системи. Другий підхід характерний для типу систем із достатнім досвідом їх розроблення. Якщо встановлено єдину цільову функцію ефективності щодо вибору параметрів системи, задача матиме однокритеріальну модель [19]. Для параметричного синтезу систем за однокритеріальними моделями використовуються методи теорії операцій. Однокритеріальні моделі $\epsilon$ простими для формування та аналізу і визначення параметрів системи, однак вони не забезпечують високої достовірності отримуваних рішень через спрощення відображення початкових задач. За наявності вектора критеріальних вимог матимемо багатокритеріальну оптимізаційну модель [9]. У цьому разі всі вимоги до параметрів системи враховуються у формі критеріїв. Задача параметричного синтезу за багатокритеріальною моделлю розв'язується або методом зведення іiі до однокритеріальної за певним критерієм [9], або альтернативними методами [19]. Для перших характерним $є$ отримання математично обгрунтованого єдиного розв'язку, що, як правило, належить до області Парето. Для альтернативних методів отримується низка розв'язків в області Парето і має місце значний суб'єктивізм в алгоритмі зведення їх до єдиного розв'язку [19].

Аналіз існуючих підходів показує, що в більшості випадків структурний i параметричний синтез ОФС систем здійснюється за однокритеріальними 
моделями, що не забезпечує повною мірою врахування усього спектра суперечливих вимог до системи і призводить до зниження якості результатів синтезу.

Окрім того, у кожному конкретному випадку для визначення оптимальної за структурою i параметрами ОФС систем обираються відповідні методи 3 урахуванням специфіки розв'язуваних цільових задач. Через це необхідним $\epsilon$ запровадження багатокритеріальних підходів до структурного і параметричного синтезу складних ОФС систем.

У [21] авторами запропоновано методику обгрунтування раціональної структури системи інформаційної безпеки Міністерства оборони та Збройних Сил України на основі методу кластерного аналізу, метою якого $є$ пошук наявних структур, що виражається в утворенні груп схожих між собою об'єктів - кластерів. Зазначений підхід дає змогу класифікувати об'єкти не за однією, а за декількома ознаками одночасно як сукупність взаємопов'язаних функціональних підсистем із визначенням функцій кожної 3 них.

У [22] авторами розглядається системноконцептуальні положення о моделюванні процесів функціонування складних багатоструктурних систем військового призначення i управління їх структурною динамікою в умовах змінювання оперативнотактичної обстановки в районі ведення бойових дій.

Аналіз відомих методологічних підходів до реалізації процесів та побудови ОФС систем i результати їх практичного застосування переконливо доводить наявність проблем у принципах побудови та методологічній базі обробки в них інформації.

Побудова відомих ОФС систем орієнтована на формування статичної надмірної структури системи i алгоритмів їх функціонування 3 рівномірним розподілом завдань між усіма іiі складовими та вибірковістю елементів лише за ї призначенням i ієрархією горизонтальновертикальних зв'язків.

Так, наприклад, збільшення кількості та щільності потоку КС i їх типів відпрацьовується через збільшення елементів структури за відповідними призначенням i рівнем, що породжує інформаційну надмірність даних для обробки. Зазначене ускладнює реалізувати динамічний перерозподіл обмежених сил і засобів спостереження i дій за загрозами та функціонування ОФС в умовах реального часу, що може призвести до зриву виконання цільових завдань реагування на КС.

Утім останнім часом широкого розвитку набули впровадження синергетичні методи в задачах управління, обробки інформації i побудови складних ОФС систем. Зокрема це стосується методів ситуативного управління.

Так у [17] авторами розроблена багатокритеріальна методика ситуаційного управління структурою i параметрами системи забезпечення інформаційної безпеки.

У [23] авторами опрацьовано математичний апарат для розв'язання задач щодо підтримання прийняття рішень під час ситуаційного управління операцією.

Організація відповідно до ситуаційного підходу розглядається як складна комплексна i багаторівнева система, у яку закладені адаптивні принципи. Завдання ситуаційної теорії - вивчати залежність методів управління від того, у якій ситуації, в яких унікальних умовах знаходиться їх організація [24].

Технологія ситуаційного аналізу передбачає виділення типових ситуацій у зовнішньому середовищі та об'єднанням цих ситуацій у блоки на основі схожих стратегій i дій керівників. За умови такого підходу головне завдання полягає в розпізнаванні ситуації, ідентифікації ऑii 3 еталонною ситуацією i передбачення на цій основі подальшого розвитку подій [24].

Зважаючи на значні розміри ОФС систем стратегічного рівня, застосування ситуаційного підходу під час синтезу ОФС загалом призведе до підвищення інерційності роботи.

3 огляду на зазначене, можна стверджувати, що традиційні підходи до побудови ОФС систем 3 упровадженням принципів ситуаційного управління спрямовані на ситуативну зміну властивостей системи завдяки формуванню унікального переліку дій відповідно до виниклої КС. Ця обставина у жодному разі не розв'язує методологічних i технологічних проблем структурного характеру, притаманних традиційним підходам до побудови складних ОФС систем i не розв'язує проблему їх ефективного функціонування в умовах значної динаміки зміни поточної ситуації і підвищення потоку КС. Зазначене потребує розвитку методів структурно-параметрічного синтезу складних ОФС систем 3 упровадженням методів багатокритеріального аналізу та ситуаційного управління.

Доцільно здійснити декомпозицію ОФС системи (системи управління Збройних Сил України та ін.) у вигляді постійної та 
флуктуаційної складових. Під постійною складовою розуміється лінійна організаційна структура підсистеми, яка характеризується: чіткістю, простотою взаємодії і управління; узгодженістю дій виконавців та інше, i, як правило, призначена для виконання завдань, які постійно повторюються. Під флуктуачійною складовою підсистеми розуміється функціональна організаційна структура, до якої закладені адаптивні принципи. Ця складова характеризується інформаційною оперативністю, розвантаженістю вищого керівництва.

Використання такого наукового методу як декомпозиція дасть змогу замінити вирішення одного великого завдання вирішенням серії менших завдань, нехай $\mathrm{i}$ взаємопов'язаних, але більш простих. Декомпозиція, як процес розділення, дає змогу розглядати будь-яку досліджувану систему як складну, що складається 3 окремих взаємопов'язаних підсистем, які, зі свого боку, також можуть бути розділеними на частини.

Так, наприклад, реалізація або адаптація, функціональної організаційної структури підсистеми під КС буде здійснюватися так: розглянемо дві ситуації - потік загроз (потенційних КС) в інформаційному просторі не змінюється, потік (потенційних КС) в інформаційному просторі суттєво збільшується і перевищує заздалегідь визначений поріг.

У першій ситуації, функціональній організаційній структурі підсистеми (ситуаційному центрі, інформаційноаналітичному підрозділу) достатньо спроможностей для виконання визначених завдань і структура системи не змінюється. У другій ситуації - ситуаційний центр (інформаційно-аналітичний підрозділ) не спроможний опрацьовувати потік (потенційних КС) в інформаційному просторі, тому створюється додатковий підрозділ для опрацювання зазначеного потоку КС. У разі зникнення загроз (потенційних КС) в інформаційному просторі зазначений підрозділ буде реорганізовуватися.

Так, наприклад, під час побудови державної системи управління силами оборони в кризових ситуаціях воєнного характеру здійснюватимемо декомпозицію системи державного управління на дві складові:

лінійна організаційна структура Верховна Рада України, Президент України, Кабінет Міністрів України, Міністерство оборони України, центральні органи виконавчої влади, Головнокомандувач Збройних Сил України, Генеральний штаб
Збройних Сил України, Командування об'єднаних сил);

функціональна організаційна структура системи ситуаційних центрів (пунктів управління) для інформаційно-аналітичної підтримки процесу управління у разі виникнення кризових ситуацій (невоєнного i воєнного характеру).

Висновки. Отже, результати проведеного аналізу свідчать, що існуючий науково-методичний апарат синтезу ОФС систем стратегічного рівня не дає змоги повною мірою врахувати нарощування інформаційних потоків, які потрібно обробляти. Особливо це є критичним під час прогнозування та реагування на КС. Найбільш перспективним підходом 3 означеного питання, який дасть змогу врахувати нові чинники, що набули актуальності за останній час, $є$ використання ситуаційного управління.

Доцільно опрацювання науковоматематичного апарату щодо декомпозиції ОФС систем стратегічного рівня на дві складові: постійної (відносно незмінної) i флуктуаційної. Синтез структури та параметрів постійної складової доцільно здійснювати за класичним трактуванням задачі параметричного синтезу складної системи. Під час синтезу структури та параметрів флуктуаційної складової доцільно використовувати ситуаційний підхід. Саме на це має сенс зосередити увагу під час подальших досліджень.

\section{СПИСОК ВИКОРИСТАНОЇ ЛІТЕРАТУРИ}

1. Про Раду національної безпеки $\mathrm{i}$ оборони України : Закон України від 05.03.1998 p. № 183/98-BP. URL: https://zakon.rada.gov.ua/laws/ show/183/98-\%D0\%B2\%D1\%80\#Text (дата звернення: 08.03.2021).

2. Гудима А. О., Гудима О. П. Ситуаційний підхід при реагуванні на глобальну фінансову кризу 2020 року. Cambridge: Education and science of today: intersectoral issues and development of sciences: Collection of scientific papers " $\Lambda \mathrm{O} Г О \Sigma$ " with Proceedings of the I International Scientific and Practical Conference. (Vol. 1). CambridgeVinnytsia : 19 March, 2021. P. 93-96. URL: https://doi.org/10.36074/logos-19.03.2021.v1.33 (дата звернення: 08.03.2021).

3. Кріндлер Джон. Передбачення кризи. Врегулювання кризових ситуацій. НАТО Ревю. НАТО, Брюссель, Бельгія. Зима, 2002. С. 17-19. URL: www.nato.int/review (дата звернення: 04.03.2021).

4. Про рішення Ради національної безпеки i оборони України від 11 березня 2021 року “Про створення Центру протидії дезінформації” : Указ Президента України від 19.03.2021 р. № 106/2021 
URL: https://www.president.gov.ua/documents/ 1062021-37421 (дата звернення: 02.03.2021).

5. Воронин А. Н. Многокритериальное распределение ограниченных ресурсов. Проблемы управления и информатики. 2010. № 4. C. $143-150$.

6. Цвиркун А. Д. Основы синтеза структуры сложных систем. Москва : Наука, 1982. 200 с.

7. Антушев Г. С. Методы параметрического синтеза сложных технических систем. Москва : Наука, 1986. $88 \mathrm{c}$.

8. Баранов Г. Л., Макаров А. В. Структурное моделирование сложных динамических систем. Киев : Наук. думка, 1986. 272 с.

9. Брахман Т. Р. Многокритериальность и выбор альтернатив в технике. Москва : Радио и связь, $1984.288 \mathrm{c}$.

10. Вермишев Ю. Х. Методы автомтического поиска решений при проектировании сложных технических систем. Москва : Радио и связь, $1982.152 \mathrm{c}$

11. Горшенин В. XXI век. Ситуационное управление как основа устойчивого развития государства. URL: http://www.rau.su/observer/N56_97/5-6_02.htm (дата звернення: 02.03.2021).

12. Клыков Ю. И. Ситуационное управление большими системами. Москва : Энершя, 1974. $136 \mathrm{c.}$

13. Цветков В. Я. Ситуационное управление образовательными учреждениями. Meтоды управления $u$ моделирования в бизнесе $u$ образовании. 2005. Вып. 9. С. 31-33.

14. Багатокритеріальні математичні моделі ситуаційного управління та самоорганізації у складних інформаційних системах : монографія / Ю. Г. Даник, О. О. Писарчук, В. І. Шестаков та ін. Житомир : Рута, 2016. 232 с.

15. Соколов К. О., Писарчук О. О., Гудима О. П. Розроблення багатокритеріальної методики ситуаційного управління структурою i параметрами системи забезпечення інформаційної безпеки. Збірник наукових праць Центру воєнно-стратегічних досліджень Національного університету оборони Украӥни імені Івана Черняховського. Київ, 2016. № 3 (58). C. 24-32.

16. Анкудинов Г. И. Синтез структуры сложных объектов: логико-комбинированный поход. Ленинград : Леингр. ун-т, 1986. 260 с.
17. Писарчук О. О. математична модель структурного параметричного синтезу складної інформаційної системи. Інформаційна безпека : зб. наук. пр. СУНУ імені. В. Даля. Сєвєродонецьк, 2010. № 1 (3). C. 38-44.

18. Дубов Ю. А., Травкин С. И., Янишец В. Н. Многокритериальные модели формирования и выбора вариантов систем. Москва : Наука, 1986. 296 c.

19. Антушев Г. С. Методы параметрического синтеза сложных технических систем. Москва : Наука, 1986. 88 с.

20. Герасимов Б. М.,

Дивизинюк М. М., Субач И. Ю. Системы поддержки принятия решений: проектирование, применение, оценка эффективности : моногр. Севастополь : СНИЯЭ и П, 2004. $320 \mathrm{c}$.

21. Косогов О. М., Сірик А. О. Методика визначення структури системи інформаційної безпеки Міністерства оборони та Збройних Сил України. Збірник наукових праць Харківського національного університету Повітряних Сил. Харків, 2017. № 3 (52). С. 30-34.

22. Підтримка вироблення рішень під час ситуаційного управління операцією (боєм): методичне забезпечення / О. М. Загорка, А. А. Корецький, І. О. Загорка, Т. М. Комолаєва // Збірник наукових праць Центру воєнностратегічних досліджень Національного університету оборони України імені Івана Черняховського. Київ, 2020. № 1 (68). С. 98-109.

23. Принципи, методи і технології моделювання i дослідження процесів функціонування складних багатоструктурних систем військового призначення i управління їх структурною динамікою / Д.А. Гриб, Б. О. Демідов, Ю. Ф. Кучеронко, А. М. Ткачов, С. В. Шубін // Системи обробки інформації. Харків, 2019. № 1 (156). C. 64-73. DOI: https://doi.org/10.30748/ soi.2019.156.09.

24. Ситуаційний підхід в теорії організації. URL: https://studme.com.ua/1056041211177/ekonomika/ situatsionnyy_podhod_teorii_organizatsii.htm (дата звернення: $02.03 .202 \overline{1}$ ).

Стаття надійшла до редакції 09.04.2021

\section{Analysis of the scientific and methodological apparatus of formation of organizational and functional structures of the strategic level}

\section{Annotation}

Modern international conflicts can no longer be assessed in terms of traditional approaches to warfare, they can be described in one term - hybrid warfare, which is a combination of traditional and non-traditional methods of warfare. In addition, each country in the world is constantly faced in various areas of its activities with threats that may affect the economic performance and stability of the state itself. Each threat (potential and real) can turn into a crisis situation of different levels.

The results of the analysis show that the existing scientific and methodological apparatus of synthesis of organizational and functional structures of the strategic level does not allow to fully taking 
into account the increase in information flows that need to be processed. This is especially critical when forecasting and responding to crisis situations. The most promising approaches to this issue, which will take into account new factors that have become relevant recently, in particular, such as information redundancy and others are the use of situational management.

It is expedient to study the scientific and mathematical apparatus for the decomposition of organizational and functional structures of the strategic level into two components: constant (relatively constant) and fluctuation. The synthesis of the structure and parameters of the constant component should be carried out according to the classical interpretation of the problem of parametric synthesis of a complex system. In the synthesis of the structure and parameters of the fluctuation component is advisable to use a situational approach.

Keywords: scientific and methodical apparatus; organizational and functional structure; situational management; crisis situation, redundancy; structural-parametric synthesis. 